\title{
Analysis of Anatomical Characteristics for Wood Species Identification of Commercial Plywood in Korea ${ }^{1}$ (ap
}

\author{
Hyun Mi LEE ${ }^{2, \dagger} \cdot$ Woo Seok $\mathrm{JEON}^{3} \cdot$ Jei Wan LEE $^{4}$
}

\begin{abstract}
International efforts to prevent illegally logged wood are expanding around the world. The "Legal Wood Trade Promotion System" was enacted in Korea in 2019 to strengthen the legal import and distribution of commercial wood in Korea. Since then, this system has promoted and ensured that the imported wood and wood products are legal with respect to the country of origin, wood species, and harvested area. As verification methods, DNA analysis technology and anatomical analysis using a microscope are mainly used in conjunction. Therefore, in this study, wood species of plywood were identified by analyzing the anatomical characteristics of various wood products for the first time. Douglas fir (Pseudotsuga menziesii (Mirb.) Franco.) and larch (Larix kaempferi (Lamb.) Carriere) plywoods (7, 9 ply) were obtained from four companies that supply plywood in Korea. After cutting each company's plywood to a size of about $1 \mathrm{~cm}^{3}$, the layers from top to bottom were separated into single layers, and three sections were observed using an optical microscope. The results revealed that the plywood was composed of a mixture of softwood and hardwood wood species, pine wood species, poplar wood species, or a mixture of larch and pine wood species. Identification of wood species using microscopy is important and can enable the scientific analysis and verification of various wood products, including plywood, imported from countries where the likelihood of indiscriminate distribution of illegal wood and illegal logging is high.
\end{abstract}

Keywords: legal wood, plywood, anatomical analysis, wood identification

\section{INTRODUCTION}

Korea depends on imports for $83 \%$ of its demand for wood, and accounts for the majority of exports of wood products by reprocessing and exporting imported raw materials. Contributions to global forest protection have prompted the enactment of international laws and timber regulations such as the Lacey
Act in the US, the European Union Timber Regulation and, more recently, the Australian Illegal Logging Prohibition Act (Koch et al., 2015). In order to protect the domestic timber industry and actively participate in international efforts, the "Act on The Sustainable Use of Timbers" was amended on March 21, 2017, and enforced on October 1, 2018, so that only legally logged wood can be handled. Items subject to import

\footnotetext{
${ }^{1}$ Date Received August 17, 2021, Date Accepted October 18, 2021

${ }^{2}$ Division of Timber Engineering, National Institute of Forest Science, Seoul 02455, Republic of Korea

${ }^{3}$ Research \& Development Team, Eagon Industrial CO, LTD, Incheon 04001, Republic of Korea

${ }^{4}$ Division of Forest Genetic Resources, National Institute of Forest Science, Seoul 02455, Republic of Korea

$\dagger$ Corresponding author: Hyun Mi LEE (e-mail: leehm2986@korea.kr, ORCID: 0000-0002-1031-3348)
} 
declaration under Article 18-3 of the "Act on The Sustainable Use of Timbers" include raw timber, sawn timber, preserved timber, fire-retardant wood, laminated wood, plywood, and wood pellets. In addition, wood products are considered culturally valuable to create economic value as cultural products (Han et al., 2021). As for wood used for producing plywood, the use of domestic deciduous larches, which reached the harvesting age, began in earnest due to difficulties in supply and demand owing to the rising import prices and the outflow of foreign currency due to the imports. The Korea Forest Service has been promoting administrative support for the supply of domestic resources, such as announcing the standards for plywood production using domestic wood and designating a plywood production complex in December 2004 (Korea Forest Service, 2005). Plywood is being supplied for construction and civil engineering because it has strong durability. According to the import status of each major item by the Korea Forest Service, plywood imports from Indonesia in 2021 (January-June) were $247,730 \mathrm{~m}^{3}$, signifying an increase of $1.3 \%$ compared to the same period in the previous year (Korea Forest Service, 2021).

In general, plywood is a wide panel made by laminating and bonding an odd number of veneers such that the wood grain direction of the veneers is perpendicular to each other. All the layers are veneers but are sometimes made with lumber or particleboard as a core. Plywood is used in various ways, such as for formwork, as interior and exterior materials for construction, and for making furniture. In the early 1990s, Korea's plywood industry faced an unstable supply-and-demand situation for tropical wood raw timber, exacerbating the difficulty in supply and demand for raw materials. Hence, mixed softwood and hardwood plywood was used. In addition, research on ways to improve the use and development of domestic needleleaf trees has been conducted, and anatomical studies are also being conducted on evaluating their suitability for making pulp and paper materials (Marbun et al., 2019; Kim et al., 2020). For domestic and imported wood that are difficult to distinguish with the naked eye, DNA analysis technique, a new wood species identification method, is conducted simultaneously to compliment wood anatomical analysis. This is because a standardized DNA extraction method needs to be established based on the various processing types of wood and the elapsed period of wood according to the distribution process. It is difficult to identify the species of processed imported wood with the naked eye, and DNA analysis is more useful because it enables the species-level identification of samples compared to wood anatomical techniques, which enables only genus-level identification (Jang et al., 2014). Therefore, for wood products that are difficult to identify via microscopy, DNA analysis is used. The prominent characteristics of plywood manufactured using softwood and hardwoods are the distribution of knots and its influence on the strength of immature wood, the different cambiums by region, estimation of planting and harvesting time, and the relatively low production yield (Jin, 1994; Park et al., 2015; Yoo et al., 2021). A study in 1999 examined the possibility of manufacturing plywood using domestic softwood Larch and using it for constructing wooden structures, with the aim of promoting industrialization by improving the added value of the domestic wood industry (Lee et al., 2018). In the plywood manufacturing process, adhesive performance is a major factor that influences the quality of the plywood. In addition to the filler of the adhesive for plywood, the adhesive strength of the plywood is not only affected by the resin content of the surface but also largely depends on the penetration of the adhesive into the wood (Ko and Roh, 2015; Roh and Kim, 2018). Adhesive penetration into the wood tissue is in the order of ray cells, tracheid, and vessels in soft- 
woods, and in the order of pore, ray cells, and fiber in hardwoods. The species used to make plywood are Katsura, Beech, Cypress, Zelkova, Maple, Chestnut, Cherry, Cedar, Pine, Abies, Oak, Walnut, Machilus, Sawara cypress, Apitong, Ash, Ebony, Mahogany, Padouk, Larch, Red lauan, Teak, etc. (Kim, 2008). Korean Pine trees are commonly used not only to manufacture plywood but also to extract their components (Min et al., 2019).

Koch (2015) stated that wood identification is very important for consumer protection as lower grade alternative wood is being imported at a noticeably increasing rate. Also, the necessity of anatomical analysis of wood to identify major species was raised in France considering that the supply of tree species for plywood manufacturing has diversified. Findings of such analysis can be used as basic data detailing the anatomy and characteristics of the species of wood to be used for repairing wooden cultural assets (Passedat et al., 2009; Han et al., 2016; Lee and Bae, 2021). In this study, species identification of plywood was performed to reveal the importance of the anatomical analysis of wood products according to the distribution of legal wood and the anatomical characteristics of mixed light hardwood plywood distributed in Korea.

\section{MATERIALS and METHODS}

\subsection{Materials}

Samples were obtained from four companies trading plywood from major domestic plywood producers. Douglas fir (Pseudotsuga menziesii (Mirb.) Franco.) and Larch (Larix kaempferi (Lamb.) Carriere) plywoods of standard size $[14.5(15) \times 1,220 \times 2,440 \mathrm{~mm}]$ sold by each company were purchased and analyzed. The species with the highest sales volume among 7 ply and 9 ply was selected (Fig. 1).

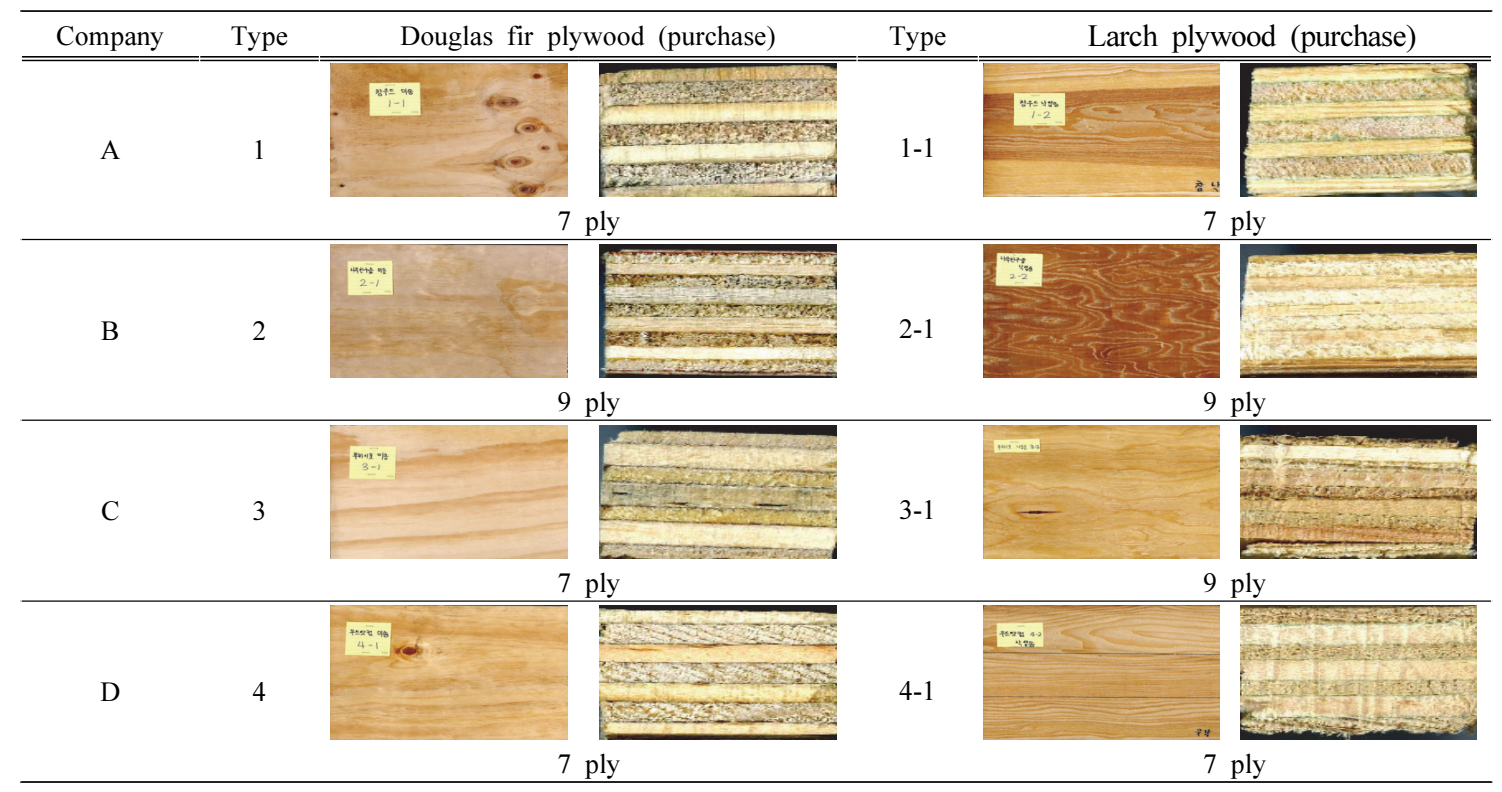

Fig. 1. Four companies supplying softwood plywood in Korea.

A company 1(Pseudotsuga menziesii), 1-1(Larix kaempferi); B company 2(Pseudotsuga menziesii), 2-1(Larix kaempferi); C company 3(Pseudotsuga menziesii), 3-1(Larix kaempferi); D company 4(Pseudotsuga menziesii), 4-1(Larix kaempferi) 


\subsection{Experimental methods}

Softwood plywood (Douglas fir and Larch) was cut to about $1 \mathrm{~cm}^{3}$ in size to identify the species of each layer. This was immersed in distilled water for about 2 days, and all the layers were separated from the face to the back using a cross-sectional view (Fig. 2). Sections with a thickness of 15-20 $\mu \mathrm{m}$ were prepared from the separated veneer using a sliding microtome. The three prepared sections were stained with $1 \%$ safranin (Jourez et al., 2001), dehydrated with increasing concentrations of ethyl alcohol $(50 \%, 70 \%, 90 \%, 95 \%$, and $99 \%$ ), and then observed under an optical microscope (Imager A1, Carl Zeiss, Germany).

\section{RESULTS and DISCUSSION}

\subsection{Anatomical characteristics}

\subsubsection{Characteristics of the three sections of the plywood}

Analysis of the multiple types of plywood with the highest sales volume in domestic plywood companies was performed based on the thickness of the plywood and the number of veneers. Larch was included in the main forest plantation species detailed in the Basic Forest Policies that began to be implemented in 1973. Since 2000s, its new uses as structural lumber and laminated wood have been established, making it a representative timber resource dominating the era of domestic timber (Bae et al., 2012). Hemlock, Douglas fir, and Spruce imported from North America were all called "Pinus menziesii" in the Korean raw wood market in the 1960s and 1970s. This is because the bark of all three species was similar to that of a pine tree. However, Douglas fir is the correct name, not "Pinus menziesii" or "Pinus koraiensis", another name for "Pinus menziesii."

In Table 1, 1 and 1-1 are the same company, as are 2 and 2-1, 3 and 3-1, and 4 and 4-1. The plywood from company 1 ( 7 ply) was made with a Pinus species of the Pinaceae family. The cross section of the face layer was indistinguishable as it was too thin to

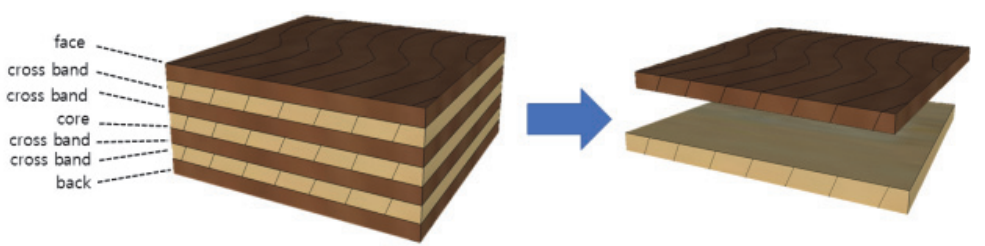

Fig. 2. Plywood separation.

Table 1. Wood properties of useful wood species from Korea

\begin{tabular}{|c|c|c|c|c|}
\hline Species & Country of production & Distribution company (ply) & Softwood Hardwood & Wood composition \\
\hline \multirow{4}{*}{ P. menziesii } & \multirow{4}{*}{ Korea } & $1(7)$ & Softwood & Face unknown, Pinus species \\
\hline & & $2(9)$ & Hardwood & Populus species \\
\hline & & $3(7)$ & Softwood & Pinus species \\
\hline & & $4(7)$ & Softwood Mix & Pinus species \\
\hline \multirow{4}{*}{ L. kaempferi } & \multirow{4}{*}{$\begin{array}{c}\text { Overseas } \\
\text { country }\end{array}$} & $1-1(7)$ & Softwood Mix & L. kaempferi, Pinus species \\
\hline & & $2-1(9)$ & Softwood Hardwood & L. kaempferi, Populus species \\
\hline & & $3-1(9)$ & Softwood Hardwood & L. kaempferi, Populus species \\
\hline & & $4-1(7)$ & Softwood Mix & L. kaempferi, Pinus species \\
\hline
\end{tabular}


perform hand-cutting. The remaining layers $2-7$ were observed to be made with a Pinus species of the Pinaceae family (Fig. 3). The tissue components of tracheid, vertical and horizontal vessels, the epithelial cells, ray parenchyma, and ray tracheid found in Pinus species were identified. The characteristic tissues were the ray tissues in the radial section with pinoid pits. The tangential section was composed of uniseriate and fusiform rays (Jeong and Park, 2008; Eom 2005; Kim et al., 2018; Kwon, 2020). The sample from company 1-1 (7 ply) was made of a mixture of softwood, and the layers were observed to be made of Larch $(1,3$,

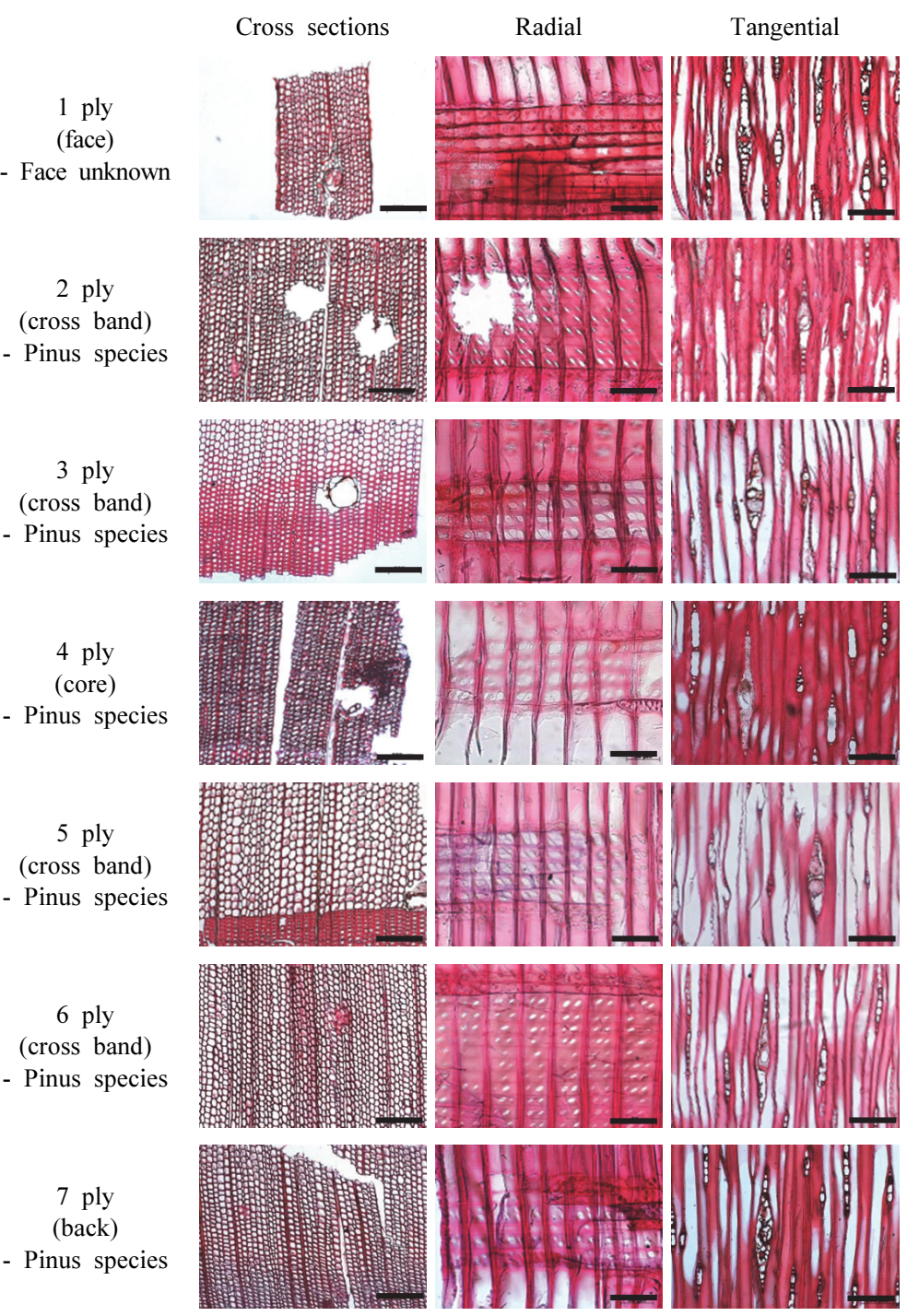

Fig. 3. Light microscope images on the plywood 3 sections(1).

Figure legends: tracheid, epithelial cells, parenchyma cells, cross-field pits, axial - radial intercellular canals $(1 \sim 7)$ 
5, and 7 layers) and Pine (2, 4, and 6 layers) (Fig. 4). As a larch of the Pinus species, there were vertical vessels in the cross section, the ray tissues in the radial section had ray parenchyma and a ray tracheid with piceoid or cupressoid pits, and the tangential section was composed of uniseriate and fusiform ray tissues. In addition, it had horizontal and vertical epithelial cells (Han, 2017). The sample of company 2 (9 ply) shown in Fig. 5 was made with Populus species of the willow family (1-9 ply). It was made with Populus

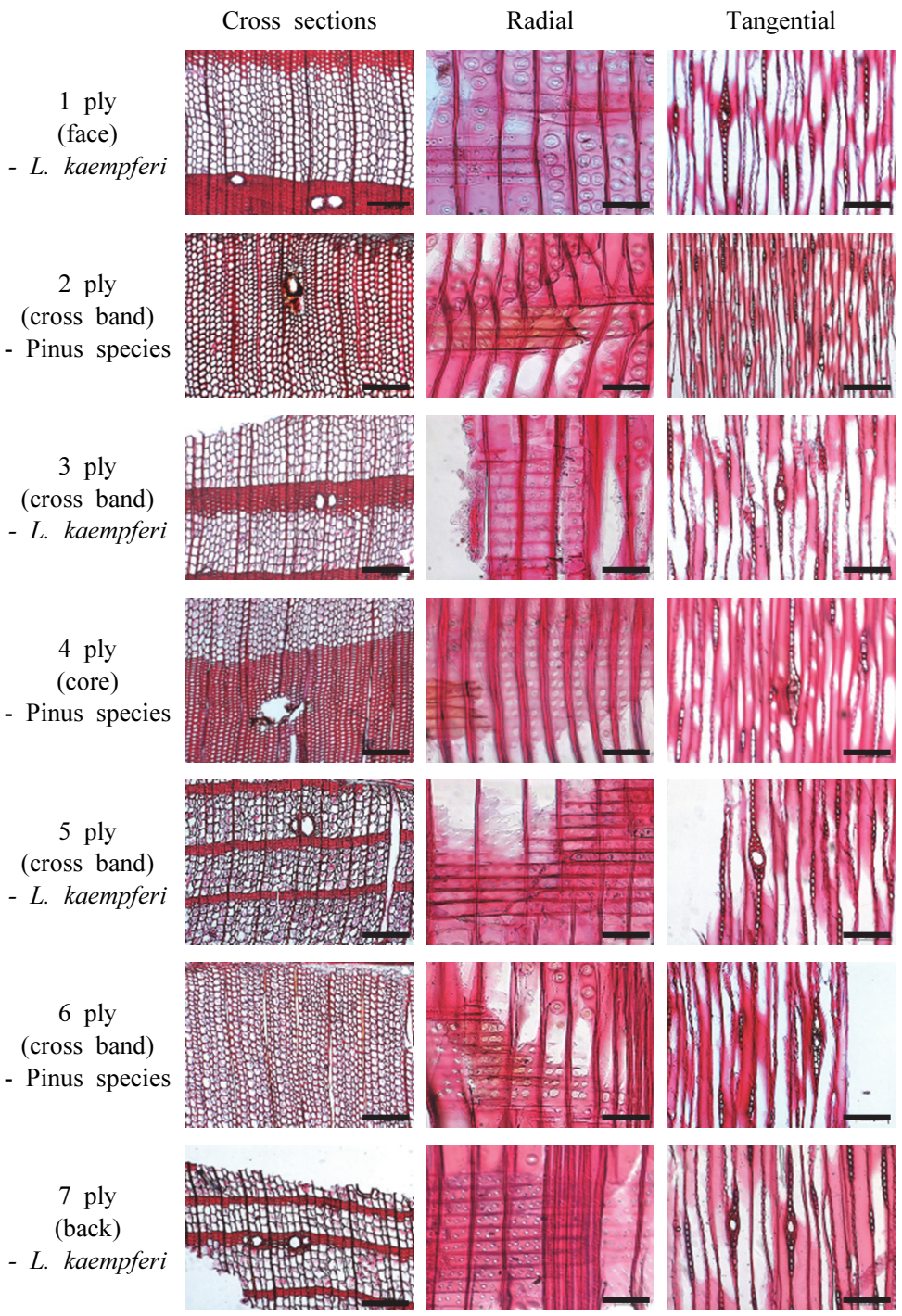

Fig. 4. Light microscope images on the plywood 3 sections(1-1).

Figure legends: tracheid, epithelial cells, parenchyma cells, cross-field pits, axial - radial intercellular canals $(1,3,5,7)$

Figure legends: ray tracheid, axial intercellular canals, piceoid pits or cupressoid pits, ray parenchyma cells, epithelial cells $(2,4,6)$ 


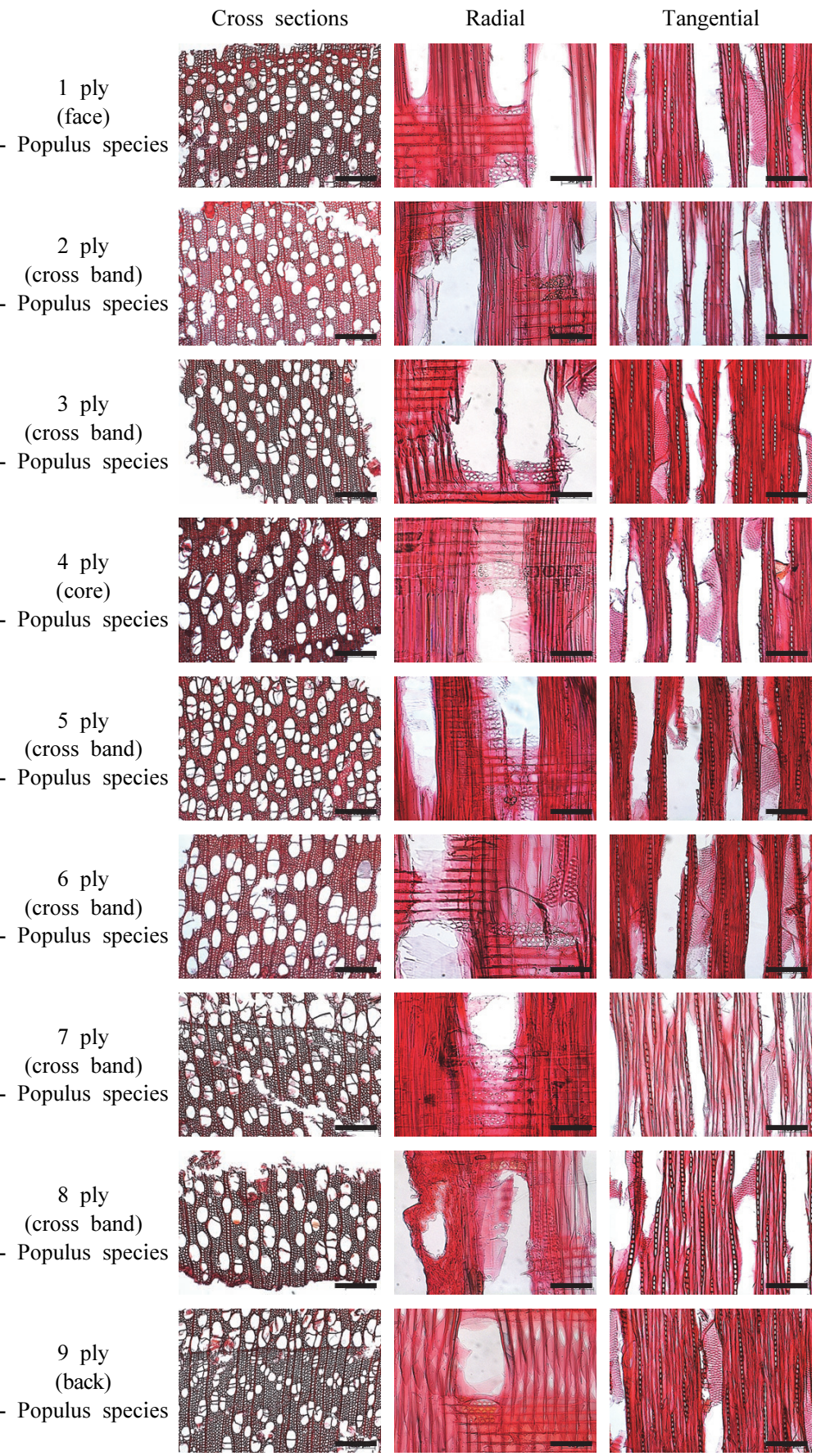

Fig. 5. Light microscope images on the plywood 3 sections(2).

Figure legends: diffuse porous wood, perforation plate, simple perforation, axial parenchyma $(1 \sim 9)$ 
Analysis of Anatomical Characteristics for Wood Species Identification on Commercial Plywood in Korea

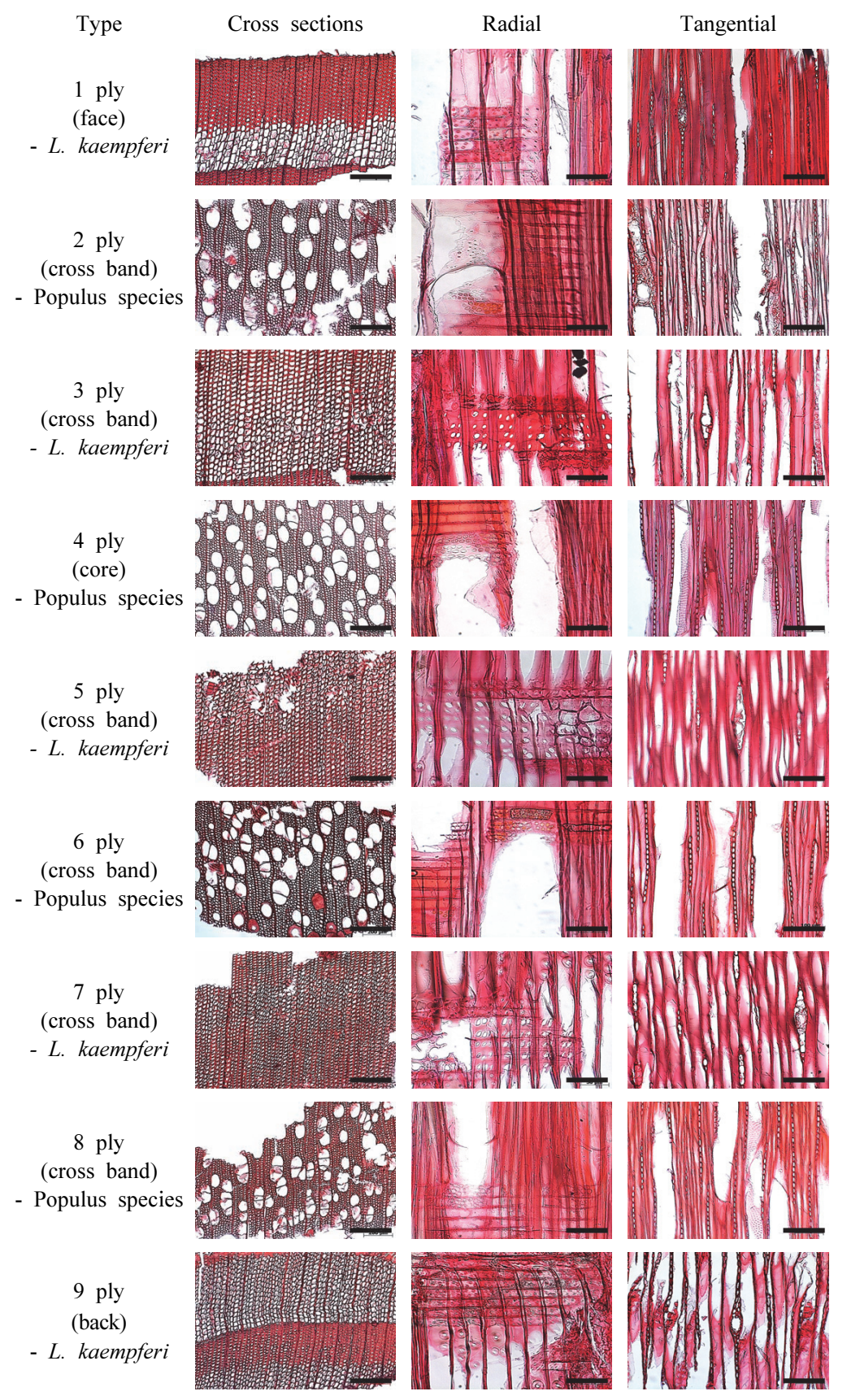

Fig. 6. Light microscope images on the plywood 3 sections(2-1).

Figure legends: tracheid, epithelial cells, parenchyma cells, cross-field pits, axial • radial intercellular canals $(1,3,5,7,9)$

Figure legends: diffuse porous wood, perforation plate, simple perforation, axial parenchyma(2, 4, 6, 8) 
species of the willow family (1-9 ply). It was a diffuse-porous wood with pores of almost constant diameter evenly distributed in the cross section throughout the annual rings. The vessel element had a simple perforation plate. The rays consisted only of uniseriate rays, and parenchyma cells were arranged longitudinally (Jeon, 2020). The sample of company 2-1 (9 ply) had a mixture of $\operatorname{Larch}(1,3,5,7$, and 9 layers $)$ and Poplar (2, 4, 6, and 8 layers) ply (Fig. 6). The characteristic tissue structure was identical to Fig. 3 and 4 . The sample of company 3 (7 ply) was observed to be made of a Pinus species of the Pinaceae family (Fig. 7), and that of company 3-1 (9 ply) was made of Larch (1-8 ply) and Poplar (9 ply) (Fig. 8), i.e.,

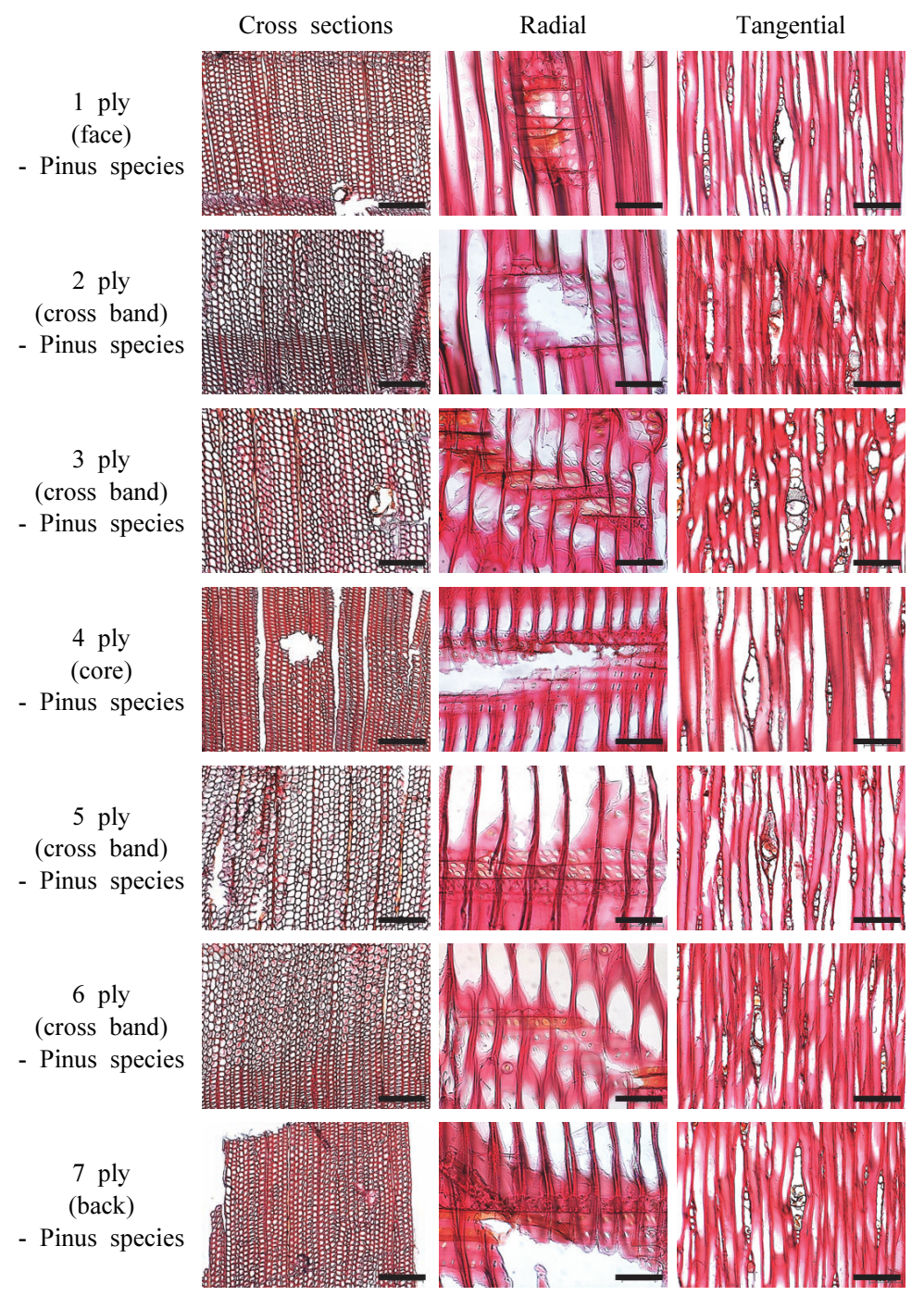

Fig. 7. Light microscope images on the plywood 3 sections(3).

Figure legends: tracheid, epithelial cells, parenchyma cells, cross-field pits, axialradial intercellular canals $(1 \sim 7)$ 


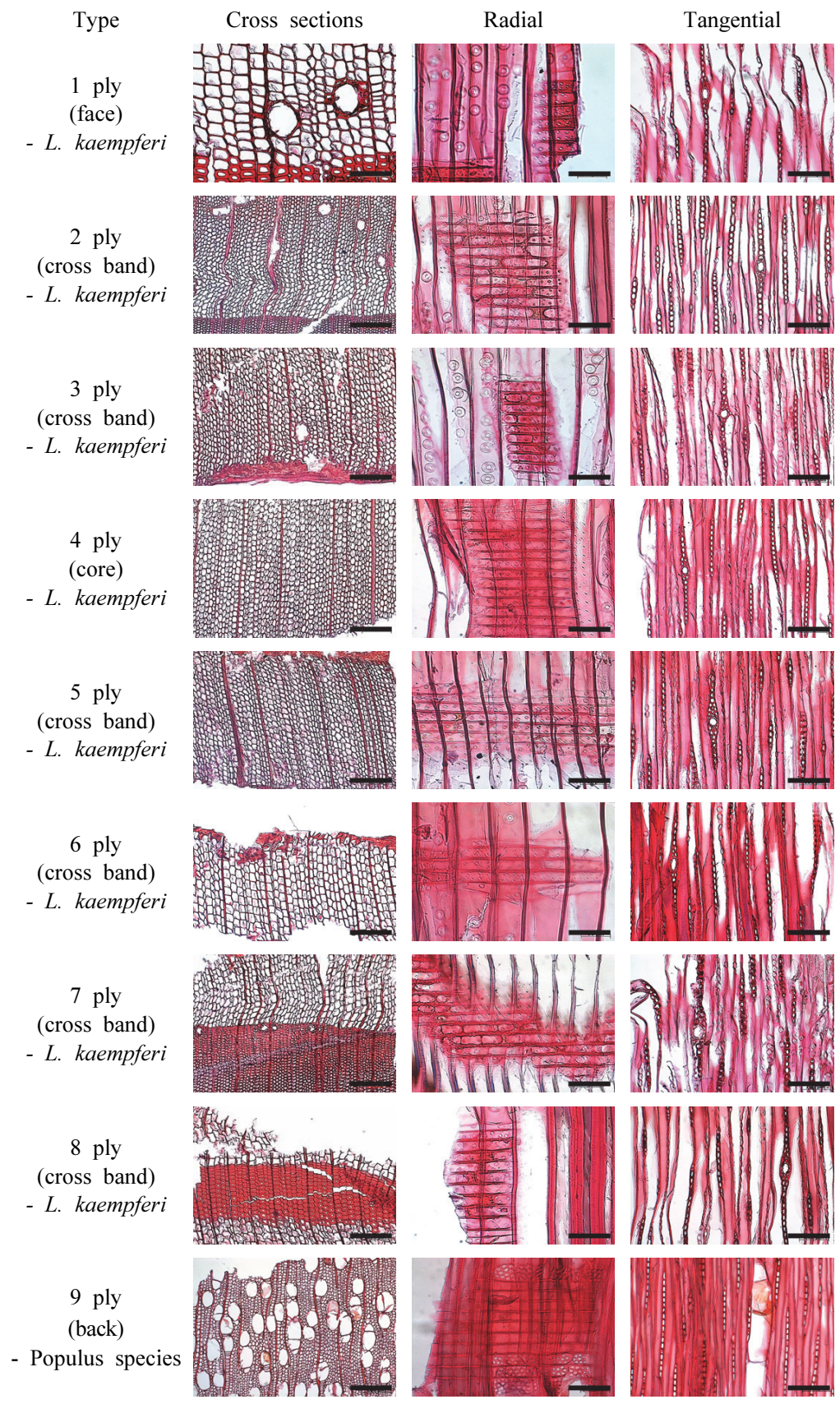

Fig. 8. Light microscope images on the plywood 3 sections(3-1).

Figure legends: tracheid, epithelial cells, parenchyma cells, cross-field pits, axial $\cdot$ radial intercellular canals $(1 \sim 8)$

Figure legends: diffuse porous wood, perforation plate, simple perforation, axial parenchyma $(9)$ 
only the back layer of the sample of company 3-1 was identified to be a Populus species. The sample of company 4 ( 7 ply) shown in Fig. 9 was observed to be a Pinus species of the Pinaceae family, and that of company 4-1 (7 ply) shown in Fig. 10 had Larch (1, 3, 5, and 7 layers) and Pine (2, 4, and 6 layers) ply (IAWA, 1989, 2004; Jeong and Park, 2008; Eom,
2015; Eom, 2018). Their anatomical description was identical.

In conclusion, the layers of Douglas fir plywood from different companies did not match, but the layers of Larch plywood from every company did match.

Therefore, since the "deception of tree species" occurs in the production or distribution of plywood,

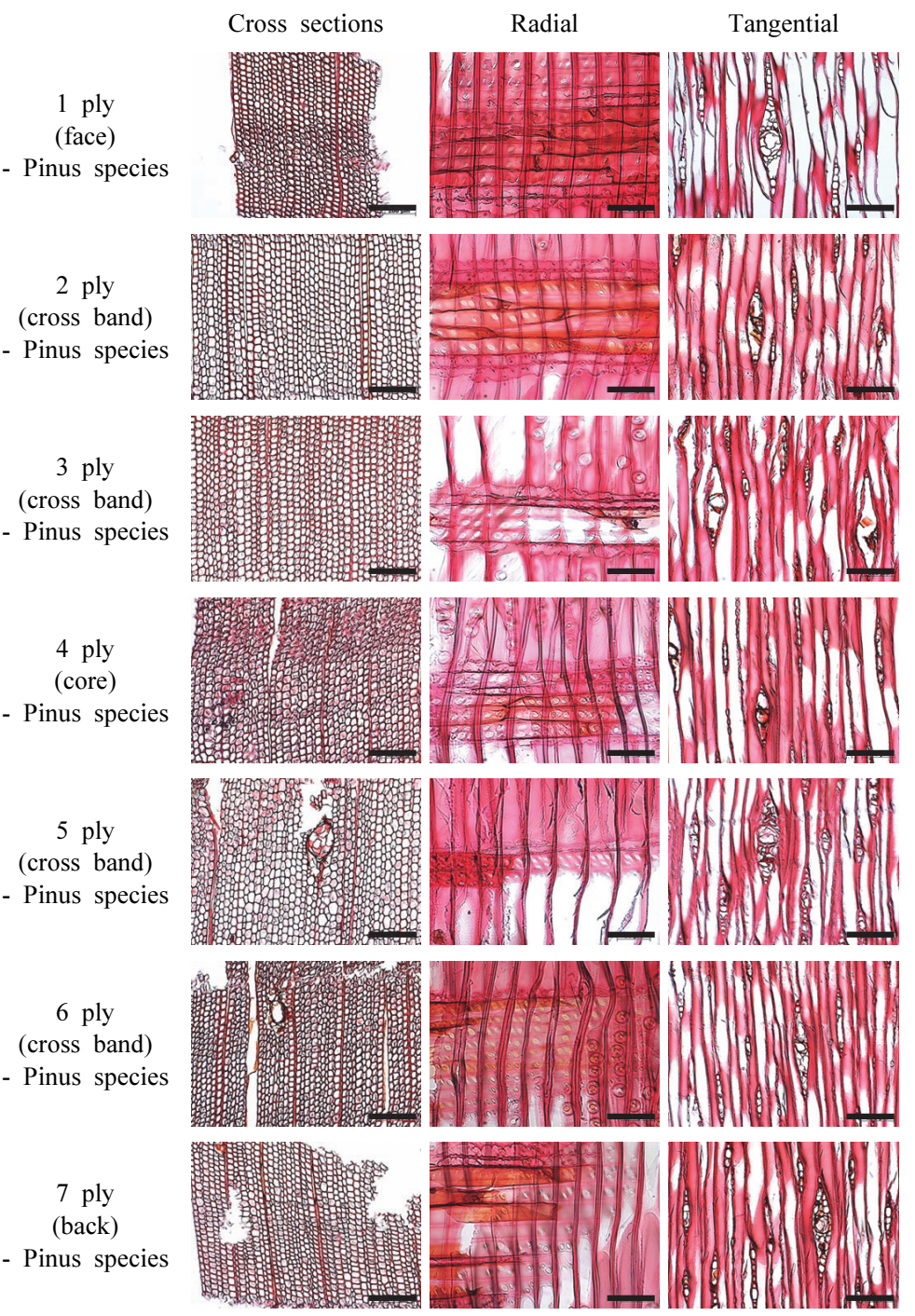

Fig. 9. Light microscope images on the plywood 3 sections(4).

Figure legends: tracheid, epithelial cells, parenchyma cells, cross-field pits, axial $\cdot$ radial intercellular canals $(1 \sim 7)$ 
this will play an important role in protecting the wood industry by identifying the species used in domestically distributed and imported plywood and provide reliable measures.

\section{CONCLUSION}

In this study, plywood distributed by domestic distributors was compared and analyzed based on anatomical characteristics. The Douglas fir and Larch ply-

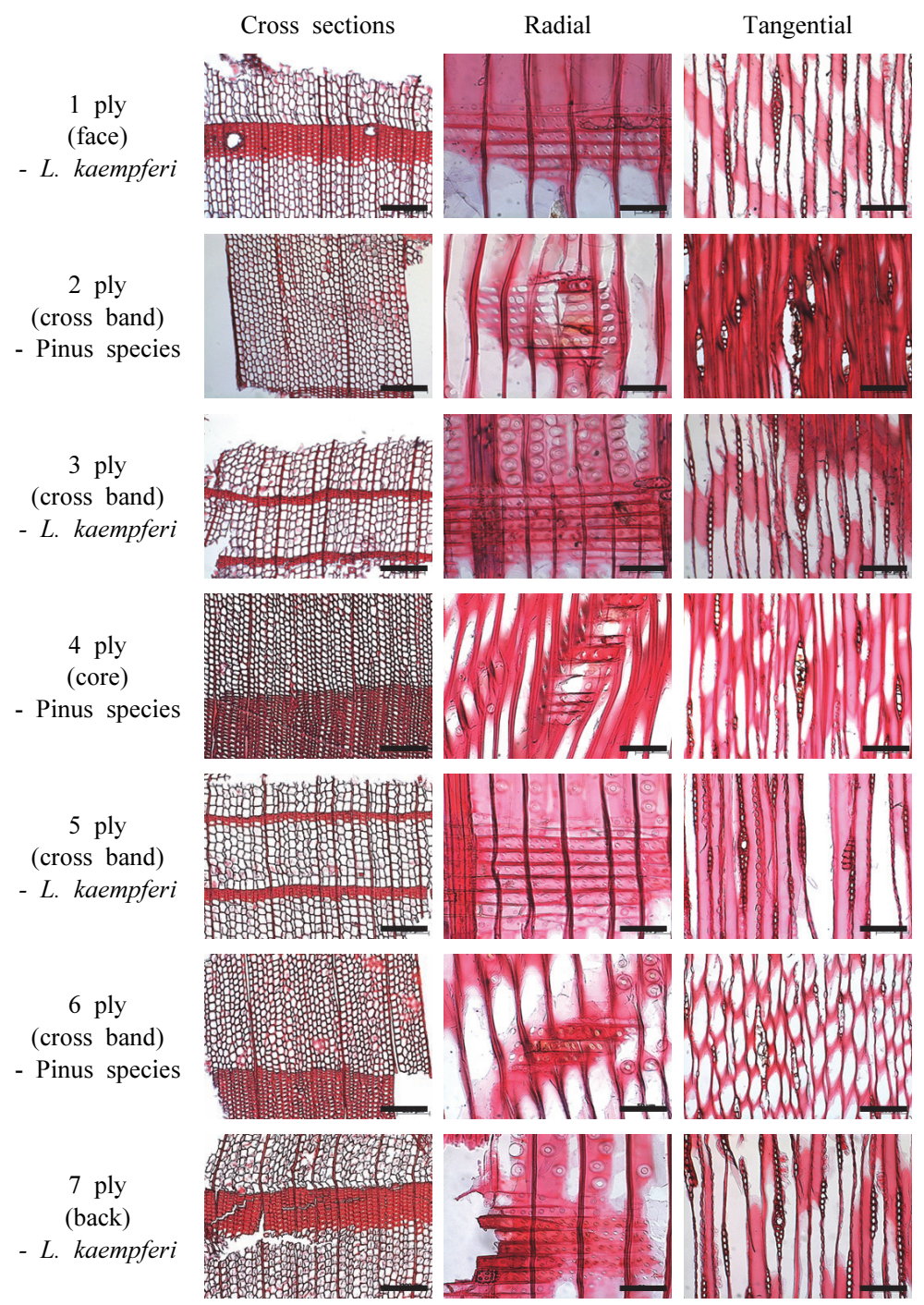

Fig. 10. Light microscope images on the plywood 3 sections(4-1).

Figure legends: tracheid, epithelial cells, parenchyma cells, cross-field pits, axial $\cdot$ radial intercellular canals $(1,3,5,7)$

Figure legends: tracheid, epithelial cells, parenchyma cells, cross-field pits, axial $\cdot$ radial intercellular canals $(2,4,6)$ 
woods of the four companies were found not to be made of a single species but rather a mixture of softwood and hardwood. Further, the species used for making the face layer to the back layer were found to be different.

Among the domestically manufactured plywoods sold as Douglas fir, three 7 ply plywoods were made of Pinus species and one 9 ply plywood was made of Populus species. Among the Larch plywoods manufactured overseas, two 7 ply plywoods were not made from a single tree species but rather a mixed species of Larix and other Pinus species and two 9 ply plywoods were made of mixed species of Larix and Populus species. This study provides basic data for tree species identification for wood and wood products imported and distributed in Korea.

\section{REFERENCES}

Bae, S.G., Lim, J.H., Kim, S.J., Lee, M.B. 2012. Economic Tree(4) Larch. Research application. National Institute of Forest Science, pp. 135-145.

Eom, Y.J., Park, B.D. 2018. Wood species identification of documentary woodblocks of Songok Clan of the Milseong Park, Gyeongju, Korea. Journal of the Korean Wood Science and Technology 46(3): 270-277.

Eom, Y.G. 2015. Wood anatomy of Korean species. Published by MEDIA WOOD., Ltd, Seoul, Republic of Korea.

Han, Y.J., Lee, H.M., Eom, C.D. 2016. Physical and mechanical properties of Korean red pine wood form different sites and correlations between them. Journal of the Korean Wood Science and Technology 44(5): 695-704.

Han, Y.J., Kim, M.J., Lee, H.M., Kang, J.T., Eom, C.D. 2017. Comparison of cellular anatomical physical and mechanical properties between Dahurian Larch and Japanese Larch. Journal of the Korean Wood
Science and Technology 45(5): 525-534.

Han, Y.J., Lee, S.M., Choi, J.Y., Park, C.Y. 2021. A study on classification of wood cultural resources in South Korea. Journal of the Korean Wood Science and Technology 49(5): 430-452.

IAWA Committee. 1989. IAWA list of microscopic features for hardwood identification by an IAWA Committee. E.A. Wheeler, P. Bass \& P.E. Gasson (eds.). IAWA Bull. n. s. 10: 235-330.

IAWA Committee. 2004. IAWA list of microscopic features for softwood identification by an IAWA Committee. H. G. Richter, D. Grosser, I. Heinz \& P.E. Gasson (eds.). IAWA Journal 25(1): 20-69. Jang, S.R., Jae, H.J., Kim, J.H., Febrianto, F., Kim, N.H. 2014. Anatomical characteristics of major plantation species growing in Indonesia II. Journal of the Korean Wood Science and Technology 42(6): 635-645.

Jeon, W.S., Lee, H.M., Park, J.H. 2020. Comparison of anatomical characteristics for wood damaged by Oak Wilt and sound wood from Quercus mongolica. Journal of the Korean Wood Science and Technology 48(6): 807-819.

Jeong, S.H., Park, B.S. 2008. Results of wood species identification analysis for commercial plywood in Korea. Research Application. No.29, pp. 36-56.

Jin, S.S. 1994. Research trends and development directions of plywood and similar products. Journal of the Korean Wood Science and Technology 22(3): $1-16$.

Kim, M.J., Seo, J.W., Kim, B.R. 2018. Anatomical Characteristics of Korea Red Pines According to Provinces. Journal of the Korean Wood Science and Technology 46(1): 100-106.

Kim, J.G. 2008. A study on laminated furniture for organic form and utility of Fullscale mode. Journal of the Korea Furniture Science 19(5): 319-327.

Ko, J.H., Roh, J.K. 2015. Utilization of waste bone powders as adhesive fillers for plywood. Journal 
of the Korean Wood Science and Technology 43(4): 528-537.

Kim, J.H., Yang, S.M., Lee, H.J., Park, K.H., Kang, S.G. 2020. A study on the evaluation and improvement of permeability in radial and tangential section of domestic softwoods. Journal of the Korean Wood Science and Technology 48(6): 832-846.

Korea Forest Service. 2005. Policy Press Release.

Korea Forest Service. 2021. Indonesia Wood Industry Trends, pp. 6.

Koch, G., Haag, V., Heinz I., Richter H-G., Schmitt, U. 2015. Control of internationally traded timber-The role of macroscopic and microscopic wood identification against illegal logging. Journal of Forensic Research 6(6): 1-4.

Kwon, O.K., Kim, N.H., Kim, J.S., Seo, J.W., Jeong, Y.J. 2020. Wood Anatomy, pp. 48-104.

Lee, I.J., Pack, J.H., Song, D.B., Jomg, S.I. 2018. Longitudinal bonding strength performance evaluation of Larch lumber. Journal of the Korean Wood Science and Technology 46(1): 85-92.

Lee, H.M., Bae, J.S. 2021. Major speices and anatomical characteristics of the wood used for national use specified in Yeonggeon-Uigwes of the Late Joseon Dynasty Period. Journal of the Korean Wood Science and Technology 49(5): 462-470.
Marbun, S.D., Wahyudi, I., Suryana, J., Nawawi, D.S.. 2019. Anatomical structures and fiber quality of four lesser-used wood species grown in Indonesia. Journal of the Korean Wood Science and Technology 47(5): 617-632.

Min, H.J., Kim, E.J., Shinn, S.W., Bae, Y.S. 2019. Antidiabetic activities of Korean Red Pine(Pinus densiflora) Inner Bark Extracts. Journal of the Korean Wood Science and Technology 47(4): 498-508.

Park, S.Y., Eom, C.D., Seo, J.W. 2015. Seasonal change of cambium activity of pine trees at different growth sites. Journal of the Korean Wood Science and Technology 43(4): 411-420.

Passedat, N., Reuling, D., Lanvin, J.D. 2009. A wood anatomy methodology to identify the main species used for French plywood. CAN Direct 61(1): 37-48.

Roh, J.K., Kim, Y.G. 2018. Bonding properties and resin exudation characteristics of Pitch Pine. Journal of the Korean Wood Science and Technology 46(3): 213-220.

Yoo, H.J., JU, J.D., Park, J.J., Shin, C.S., Eom, C.D., Seo, J.W. 2021. Estimation of the optimal periods for planting and felling Larix kaempferi based on the period of its cambial activity. Journal of the Korean Wood Science and Technology 49(5): 399-415. 


\title{
APPENDIX
}

\author{
(Korean Version)
}

\section{국내 유통 합판의 수종식별을 위한 해부학적 특성 분석}

초록 : 전 세계적으로 불법목재 방지를 위한 국제적 노력이 확대되고 있으며, 우리나라는 국내에 수입·유통되는 목재의 합법성을 강화하기 위하여 2019년 ‘합법목재 교역촉진제도’를 시행하고 있다. 합법목재 교역촉진제도는 목재, 목재제품 등을 수입할 시 생산 국가, 수종, 벌채지 등에 대해 합법한 목재임을 입증하는 제도이다. 입증 방법에는 주로 DNA 분석 기술과 현미경을 이용한 해부학적 특징 분석이 함께 이용되고 있다. 따라서, 본 연구에서는 다양한 목재제품 중에 우선적으로 합판의 해부학적 특성을 분석하여 수종 식별을 하였다. 공시재료는 합판 생산 기업의 합판 $7,9 \mathrm{ply})$ 을 취급하는 4 업체를 선정하여 미송(Pseudotsuga menziesii (Mirb.) Franco.) 및 낙엽송(Larix kaempferi (Lamb.) Carriere)합판을 구입하여 시료를 확보하였다. 각 회사의 합판을 약 $1 \mathrm{~cm}^{3}$ 크기로 절삭한 뒤, 표판부터 이판까지 하나의 단판으로 분리하여 광학현미경을 이용하여 3 단면을 관찰하였다. 수종식별 결과, 침·활엽수 혼합 합판과 소나무류, 포플러류, 낙엽송·소나무류의 혼합으로 구성되어 있었다.

현미경법을 이용한 목재의 수종식별은 무분별한 불법 목재의 유통 및 불법 벌채 위험국가로부터 수입되는 합판을 비롯한 다른 여러 가지 목재 제품을 과학적으로 분석·검증할 수 있는 중요한 분야이다

\section{1. 서론}

우리나라는 목재수요의 $83 \%$ 를 수입에 의존하고 있으며 수입된 원자재를 재가공하여 수출하는 경우의 목재제품 수출량의 다수를 차지하고 있다. 세계 산림 보호에 대한 기여로 미국 Lacey법, 유럽목재규정(EUTR) 및 최근에는 호주의 불법 벌목 금지법과 같은 국제법 및 목재 규정이 제정되었다(Koch et al., 2015). 우리는 국내 목재산업을 보호하고 국제적인 노력에 적극 동참하고자 「목재의 지속가능한 이용에 관한 법률」을 개정(17.3.21)하고, 18. 10월1일 시행하여 합법적으로 벌채된 목재만 을 취급할 수 있도록 하고 있다. 「목재의 지속가능한 이용에 관한 법률 시행령」제 18 조의 3 에 따른 수입신고 대상품목으로 원목, 제재목, 방부목재, 난연목재, 집성재, 합판, 목재펠릿이 있다. 또한 목재제품에 문화적 가치를 부여하고 문화상품으로서의 경제적 가치를 창출해 내고 있다(Han et al., 2021). 합판용 목재는 수입원목가의 상승으로 인한 수급의 어려움, 전량 수입에 의한 외화 유출과 일부 벌기령에 도달한 국내 낙엽송의 활용을 본격화 하였다. 산림청은 2004년 12월 국산재를 이용한 합판용재 생산을 위한 규격을 고시하고 합판용재 생산단지를 지정하는 등 국산재 공급을 위한 행정지원을 추진하여 왔다(Korea Forest Service, 2005). 합판은 내구성이 강하기 때문에 건축이나 토목용으로 공급되고 있다. 산림청 주요 품목별 수입현황을 살펴보면, 2021년(1-6월) 인도네시아 합판수입은 24만7,730 3 으로 전년 동기 대비 $1.3 \%$ 증가하였다(Korea Forest Service, 2021).

일반적으로 합판이란 홀수 매의 단판을 목리방향이 서로 직교되도록 적층 접착시켜 만든 넓은 판상재로 모든 층재는 단판이 나, 때로는 럼버 또는 파티클보드를 코어로 구성하여 제조하는 판재이다. 용도는 거푸집, 건축용 내·외장재, 가구 등 다양하게 사용되고 있다. 1990년대 초반 우리나라 합판 산업은 남양재 원목의 불안정한 수급 상황의 국면을 맞으면서 원자재 수급난이 가중되고 침-활엽수 혼용 합판이 활용되었다. 또한 국산 침엽수 활용에 대한 용도개발 개선방안 연구가 진행되었고, 펄프·제지 재료에 대한 적합성 평가에서도 해부학적 연구가 진행되고 있다(Marbun et al., 2019; Kim et al., 2020), 육안 구분이 곤란하고, 국산재와 수입재 수종에 대하여 목재해부학적 기법을 보완할 새로운 수종 식별 방법으로 DNA 분석법이 동시에 이루어지고 있다. 목재의 다양한 가공형태, 유통과정에 따른 목재 경과기간 등으로 표준화된 DNA 추출 방법이 정립되어져야 하기 때문이다. 한번 제재된 상태로 수입된 목재는 육안적으로는 수종식별이 어려워 목재해부학적 기법이 속 수준 식별이라면 DNA 분석법은 종 또는 개체 식별이기에 더욱 활용도가 높다(Jang et al., 2014). 그렇기 때문에 현미경법으로 식별이 어려운 목제품은 DNA 분석법을 활용하고 있다. 침엽수재와 활엽수재의 합판제조에서 가장 큰 특징은 옹이의 분포와 미성숙재의 강도 영향의 문제, 지역별 형성층과의 차이, 식재 및 벌채적기 추정, 제조 수율이 높지 않다는 점 등이 있다(Jin, 1994; Park et al., 2015; Yoo et al., 2021). 한편, 국내 목재산업의 부가가치를 향상시켜 산업화를 촉진하고 국산재를 적극 활용한다는 목적으로 1999년 국산 침엽수재 낙엽송을 이용한 합판제조 가능성, 목조건축 구조재 등을 타진한 연구가 시도되었다(Lee et al., 2018). 특히 합판제조 공정에 있어서 접착성능은 합판의 품질을 좌우하는 주요한 요인이다. 합판용 접착제의 충전제뿐만이 아니라, 목재 합판에 있어서 접착강도는 표면의 수지분에 의해서도 영향을 받지만 목재내부로의 접착제의 침투성에 의해서도 크게 좌우된다 
(Ko and Roh, 2015; Roh and Kim, 2018). 목재조직내로 접착제침투는 침엽수재에서는 방사조직, 가도관, 수지구의 순서이고, 활엽수재에서는 도관, 방사조직, 목섬유 순서이다. 합판 제작에 사용되는 수종은 계수나무, 너도밤나무, 노송나무, 느티나무, 단풍나무, 밤나무, 벚나무, 삼나무, 소나무, 전나무, 졸참나무, 호두나무, 후박나무, 화백나무, 아피통(apitoug), 에쉬(ash), 에보니 (ebony), 마호가니(mahogany), 파덕(padouk), 포플리(poplar), 붉은 나왕(red lauan), 티크(teak) 등이다(Kim, 2008). 한국산 소나무는 합판 제조뿐만이 아니라 추출성분까지도 많이 이용되고 있다(Min et al., 2019).

Koch (2015)는 낮은 등급의 대체 목재가 눈에 띄게 증가하는 속도로 수입되기 때문에 소비자 보호를 위해서도 목재 식별은 매우 중요하다고 하였다. 또한 프랑스에서는 합판을 제조하는데 있어서 수종의 공급이 다양화됨에 따라 주요 종을 식별하기 위해 목재 해부학적 방법론이 필요하다고 하였고, 목조문화재 수라·보수 시 사용될 수종에 대한 목재해부학적 기초자료와 재질특 성에 대한 기초자료로 이용될 것이다(Passedat et al., 2009; Han et al., 2016; Lee and Bae, 2021). 본 연구는 합법목재 유통에 따른 목제품에 대한 목재 해부학적인 과학적 분석의 중요성과 국내 유통되고 있는 MLH (Mixed Light Hardwood) 합판에 대한 해부학적 특징을 밝히고자 합판의 수종식별을 수행하였다.

\section{2. 재료 및 방법}

\section{1. 공시재료}

국내 주요 합판 생산 기업의 합판을 취급하는 4 개의 업체를 대상으로 시료를 확보하였다. 각각의 업체에서 미송과 낙엽송으로 판매되고 있는규격 $14.5(15) \times 1,220 \times 2,440(\mathrm{~mm})$ 의 미송(Pseudotsuga menziesii (Mirb.) Franco.), 낙엽송(Larix kaempferi (Lamb.) Carriere)에 대한 적층수 7ply, 9ply 중에서 합판 판매량이 높은 수종을 구매하여 분석하였다(Fig. 1).

\section{2. 실험방법}

침엽수 합판(미송, 낙엽송)을 각 적층별 수종 식별을 위해 약 $1 \mathrm{~cm}^{3}$ 크기로 절삭한 뒤, 증류수에 약 2 일간 침지 시켰으며, 단면도를 이용하여 표판(face)부터 이판(back)까지 분리시켰다(Fig. 2). 분리된 단판을 활주식 마이크로톰(sliding microtome)으 로 $15 \sim 20 \mu \mathrm{m}$ 두께의 절편을 제작하였다. 제작된 3단면은 $1 \%$ 사프라닌으로 염색(Jourez et al., 2001)하고, 알코올(Ethyl Alcohol) 시리즈( $50 \%, 70 \%, 90 \%, 95 \%, 99 \%)$ 로 탈수 후, 광학현미경(Imager A1, Carl Zeiss, Germany)으로 3단면을 관찰하였다.

\section{3. 결과 및 고찰}

\section{1. 목재해부학적 특징}

3.1.1. 합판의 3단면 특징

국내 합판을 취급하는 업체를 대상으로 합판 판매량이 높은 수종, 합판의 두께 및 단판의 매수, 복수 수종 합판을 바탕으로 분석하였다. 낙엽송은 1973년 시작된 산림기본계획의 주요 조림 수종에 포함되어 2000년대부터 현재까지 구조용재나 집성재 등 새로운 용도가 개발되면서 국산재 시대를 이끌어가는 대표적인 목재 자원으로 자리잡았다(Bae et al., 2012). 우리나라 1960 1970년대 원목시장에서 미송이라고 하는 것은 북미에서 수입된 햄록(Hemlock), 더글라스 퍼(Douglas fir), 스프러스 (spruce)를 모두 미송이라고 불렀다. 세 수종 모두 수피가 소나무와 비슷했기 때문이다. 하지만, 미송의 다른 이름인 홍송도 미송도 아닌 더글라스퍼 라고 부르는 것이 맞다.

Table 1에서, 1, 1-1 동일업체, 2, 2-1 동일업체, 3, 3-1 동일업체, 4, 4-1 동일업체이다업체 1(7ply)은 소나무과의 소나무류 합판으로 표판은 너무 얇아서 hand-cutting도 어려워 횡단면이 식별 불가이고, 나머지 2 7판까지는 소나무과의 소나무류로 관찰되었다(Fig. 3). 소나무류에서 볼 수 있는 조직구성 요소로써 가도관, 수직·수평수지구와 이를 둘러싸고 있는 에피델리움세 포, 방사유세포 및 방사가도관이 확인되었다. 특징적인 조직은 방사단면에서의 방사조직은 소나무형벽공이다. 접선단면은 단열. 방추형방사조직으로 구성되어 있다(Jeong and Park, 2008; Eom 2015; Kim et al, 2018; Kwon 2020). 업체 1-1(7ply)은 침엽수 혼합으로 낙엽송 $(1,3,5,7 \mathrm{ply})$ 과 소나무류(2, 4, 6ply)로 관찰되었다(Fig. 4). 소나무과의 낙엽송으로써 횡단면은 수직수지구가 존재하고 방사단면에서의 방사조직은 가문비나무형 또는 편백형벽공을 가지는 방사유세포와 방사가도관이 존재하고, 접선단면 은 단열·방추형방사조직으로 구성되어 있다. 또한 수평수지구와 수지구의 에피델리얼세포가 존재한다(Han, 2017). Fig. 5의 업체 2(9ply)는 버드나무과의 포플러류(1 9ply)로써 횡단면에서는 지름이 거의 일정한 관공이 열륜 전체에 걸쳐서 고르게 흩어져 있는 산공재이고 도관요소의 천공판은 단천공이다. 방사조직은 단열방사조직으로만 구성되어 있고 축방향 유세포가 존재한다(Jeon, 2020). 업체 2-1(ply)는 적층별로 낙엽송(1, 3, 5, 7, 9ply)과 포플러류(2, 4, 6, 8ply)가 혼합되어 있다(Fig. 6). 
식별의 특징적인 조직구성은 Fig. 3, 4와 동일하다. 업체 3(7ply)은 소나무과의 소나무류로 관찰되었고(Fig. 7), 업체 3-1(9ply)은 낙엽송(1 8ply)과 포플러류(9ply)로 구성되어 있다(Fig. 8). 즉 마지막 이판만 포플러류로 식별되었다. Fig. 9의 업체 4(7ply)는 소나무과의 소나무류로 관찰되었다. Fig. 10 의 업체 4-1(7ply)는 낙엽송 $(1,3,5,7 \mathrm{ply})$ 과 소나무류(2, 4, 6ply)로 식별되었다 (IAWA, 1989, 2004; Jeong and Park, 2008; Eom, 2015; Eom, 2018). 해부학적 설명은 동일하다.

결과적으로 업체 미송 합판과는 일치하지 않았고, 낙엽송 합판의 경우는 모든 업체 제품의 표판이 낙엽송과 일치하였다. 따라서 합판 제작이나 유통과정에서 '수종 속임 ' 등이 이루어지기 때문에 국내 유통 및 수입되어 들어오는 합판에 대한 수종을 식별함으로써 목재산업을 보호하는 데 중요한 역할을 할 것이고 신뢰할 수 있는 이점이 있을 것이다.

\section{4. 결론}

국내 유통업체에서 유통되고 있는 합판을 해부학적 특징을 바탕으로 비교·분석하였다. 4 개 업체의 미송과 낙엽송 합판은 단일수종이 아닌 침·활엽수 혼용으로 관찰되었고 표판에서 이판까지의 수종도 다르게 나타났다.

국내 제조 미송이라고 판매된 합판 중 7 ply 3 개는 소나무류이고 9 ply 1 개는 포플러류로 관찰되었다. 국외 제조 낙엽송이라고 판매된 합판 중 $7 \mathrm{ply} 2$ 개는 단일수종이 아닌 낙엽송과 다른 소나무류 혼합수종으로 나타났고, $9 \mathrm{ply} 2$ 개도 단일수종이 아닌 낙엽송과 포플러류 복합수종으로 나타났다. 본 연구는 국내 수입되고 유통되는 목재 및 목제품에 대한 수종확인을 위한 기초자료 로 제공될 것으로 생각된다. 